\title{
EDITORIAL
}

\section{Genetics and the Epidemiology of Leprosy}

We are grateful to Dr. S. G. Spickett of Cambridge for raising this important question by his paper on the subject which appears in this issue of Leprosy Review (pp. 76-93). The study begins with a review of the variation in the incidence of leprosy in different populations. Dr. Spickett finds that the variation of populations in their susceptibility to leprosy is in part due to genetic differences, i.e. differences in gene frequency and manifestation. From his study of familial leprosy he suggests that the evidence is in favour of susceptibility to the invasion of the leprosy bacillus being controlled by a single irregularly dominant gene. There was one instance where this gene had a penetrance of $83.3 \%$.

The influence of genetic systems on the epidemiology of leprosy is of considerable interest. We are glad that Dr. Spickett will continue his studies and also appeals for collaboration in the furtherance of such studies.

\section{Leprosy Work in Ethiopia, Uganda, Northern Rhodesia and Tanganyika}

Dr. N. D. Fraser, Medical Secretary of the Mission to Lepers, made a tour of these countries in May and June, 1961, and has kindly given us an informative report on his findings which we publish in this issue (pp. 141-153). In connection with Ethiopia we also publish a report by Dr. K. F. Schaller, Chief of Leprosy Control in Ethiopia, on the proceedings of the Second National Leprosy Conference held in Addis Ababa November-December, 1961. Both these reports are of great interest and we thank the respective authors.

\section{Latex Compound for the Karigiri Boot}

In connection with the treatment of plantar ulcers (W. F. Ross in Leprosy Review, Jan. 1962) we draw attention to a letter to the Editor from R. R. Stapleton, M.Sc. (in this issue p. 154) of Dunlop Chemicals Products Division. Practical details are given which will be of value to workers on the field.

\section{Footwear in Leprosy}

This subject is also dealt with by Mr. D. Ward, M.C.S.P. of Karigiri in his paper in this issue (pp. 94-105). It is encouraging to find nowadays so much interest and study given to the orthopaedics and physiotherapy, prevention, and rehabilitation of deformities and ulcers of the feet in leprosy. 


\section{The Hyderabad Conference of January 1962}

Dr. E. Muir attended this interesting and valuable leprosy conference in India and has kindly sent his report which appears in this issue (pp. 156-161).

\section{Classification of Leprosy for Research Purposes}

Drs. D. S. Ridley and W. H. Jopling have been studying this subject and their stimulating paper appears in this issue (pp. 119-128). They attempt to define 5 group classifications of leprosy in which the groups represent 5 grades of resistance of the patient to infection. They suggest we can define this resistance on clinical and histological characters and by reference to the bacteriological response to treatment. Their basic idea seems eminently practical and it would be interesting to have their scheme worked out in full with all relevant details for each of the five groups. Also we have the useful paper by Dharmendra and S. N. Chatterjee (this issue, pp. 106-118) on the Indian view of maculo-anaesthetic leprosy and its relation to classification.

\section{Lepromin Reaction}

Kooij and colleagues contribute an interesting paper (this issue, pp. 129-140) on the lepromin reaction evoked by normal liver preparations. 